\title{
PENDEKATAN RESTORATIF JUSTICE SEBAGAI UPAYA PENYELESAIAN CYBERCRIME DENGAN PELAKU ANAK (Studi Kasus Penyelesaian Tindak Pidana Anak Usia Sekolah)
}

\author{
Bambang Sukoco \\ Universitas Muhammadiyah Surakarta \\ bs180@ums.ac.id
}

\begin{abstract}
Abstrak
$\mathrm{H}$ ak asasi anak dilindungi di dalam Pasal 28 B Ayat (2) UUD 1945 bahwa setiap anak berhakatas kelangsungan hidup, tumbuh dan berkembang serta berhak atasperlindungan dari kekerasan dan diskriminasi. Anak yang terkena kasus hukum diduga sering tidak mendapatkan keadilan oleh hukum melalui oknum aparatnya. Misalnya seperti kejadian di Lapas Anak di Kutoarjo, dari pengamatan dan wawancara singkat dengan anak binaan dan petugas Lapas, bahwa sangat sulit mengharapkan adanya perubahan perilaku dari "pemenjaraan" anak di Lapas jikalau anak dalam tingkatan umur digabung, tidak ada pengawasan yang intens, dan tidak ada program yang memadahi guna melakukan rekontruksi perilaku. Hal ini belum bisa dipenuhi oleh Lapas Anak Kutoarjo yang merupakan salah satu Lapas Anak rujukan di Indonesia. Lapas anak hanya seperti tempat berkumpulnya anak-anak nakal, alih-alih mereka akan mendapatkan pembinaan perubahan perilaku, justru mungkin saja ini adalah tempat pembelajaran tindak kriminal bagi anak. Oleh karena itu perlu berfikir ulang untuk melakukan pemenjaraan terhadap anak melalui Restoratve Justice sebagai upaya mendatangkan keadilan dan perlindungan bersama.
\end{abstract}

Kata Kunci: Tindak Pidana Anak, Cyber Crime, Restorative Justice

\section{PENDAHULUAN}

Anak adalah permata kehidupan, begitulah ungkapan yang menggambarkan betapa anak merupakan individu yang sangat berharga dalam kehidupan dan peradaban manusia.Wajar jika dalam sebuah kesempatan, seorang aktivis dan pemerhati masalah anak yang biasa disapa Kak Seto pernah mengatakan, bahwa bangsa yang besar adalah bangsa yang bisa menghargai keberadaan anak-anak, sebab anak adalah aset masa depan. ${ }^{1}$ Anak merupakan aset bangsa yang harus dijaga dan dilindungi, untuk ke depannya anak-anak Indonesia diharapkan dapat terpenuhi segala hakhaknya untuk tumbuh dan berkembang. ${ }^{2}$ Anak adalah karunia yang terbesar bagi keluarga, agama, bangsa,dan negara. Hak asasi anak dilindungidi dalam Pasal 28 B Ayat (2) UUD 1945 yang berbunyi setiap anak berhakatas kelangsungan hidup, tumbuh dan berkembang serta berhak atasperlindungan dari kekerasan dan diskriminasi.

Anak dalam siklus kehidupan adalah sosok individu yang akan meneruskan estafet kehidupan orang dewasa dan melanjutkan eksistensi peradaban suatu bangsa. Bagaimana wajah dinamika kehidupan 20 - 30 tahun yang akan maka anak adalah jawabanya. Sebagai bahan evaluasi sederhana, kita bisa melihat bagaimana kualitas anak sekarang untuk mengetahui maju mundurnya kehidupan di suatu bangsa di masa depan. Jika sekarang anak-anak di negeri ini berkualitas, mungkin kita bisa sedikit bernafas lega, karena berarti kita mempunyai bibit-bibit pemimpin yang berkualitas. Walaupun hal itu baru berupa bayangan, kerangka atau bahkan baru sebatas mimpi, namun paling tidak ada peluang besar untuk mewujudkan mimpi itu menjadi kenyataan. Apabila saat ini anak-

1 Seto Mulyadi. Kabar Siang TV.One. 19 Januari 2014

2 Diah Permata Hildi, Tribun News, 24 Agustus 2016 
anak di negeri ini bermental bobrok atau tidak berkualitas, berarti kita telah berhadapan dengan mimpi buruk, yang untuk keluar dari mimpi buruk itu tentunya membutuhkan tenaga yang ekstra besar.

Karena begitu urgent posisi anak dalam kehidupan mendatang, maka negara sebagai pemegang otoritas dalam kehidupan berbangsa harusnya merespon permasalahan ini dengan serius. Hal ini misalnya bisa dilakukan dengan berbagai langkah, yaitu dengan memproduk peraturan-peraturan yang melindungi hak-hak anak, atau dengan membuat kebijakan-kebijakan yang mengakomodir kepentingan berpersepektif melindungi anak, sehingga anak bisa tumbuh berkembang sebagaimana mestinya dan menjadi manusia-manusia yang berkualitas dimanapun anak itu berada, baik ketika anak yang hidup "normal" dalam masyarakat ataupun bagi anak yang berhadapan dengan hukum $(\mathrm{ABH})$.

Anak yang terkena kasus hukum didugasering tidak mendapatkan keadilan oleh hukum melalui oknum aparatnya. Situasi ini berkembang menjadi buah bibir di tengah masyarakat. Masih ingat kasus AAL?, hanya karena dianggap mencuri sepasang sandal jepit di Palu, Sulawesi Tengah, ia harus menjalani sidang di peradilan. Juga kasus meninggalnya kakak beradik berusia 17 tahun dan 14 tahun di tahanan polsek Sijunjung Sumatera Barat, setelah tubuh mereka penuh luka dan memar ketika menjalani pemeriksaan. Kasus serupa juga terjadi di Jawa Timur, HDF meninggal di Lapas Tulungagung Jawa Timur, dia tewas karena dikeroyok sesama tahanan. Peristiwa lain adalah kematian RF (17) yang ditahan di Poltabes Surabaya, dia meninggal setelah dikeroyok oleh tahanan orang dewasa dalam satu selnya. ${ }^{3}$ Beberapa bulan yang lalu di Sragen, menyerat anak berinisial RS juga karena dituduh melakukan pencurian sandal jepit dan harus mendapat hukuman percobaan 2 (dua) bulan. ${ }^{4}$

Selain kasus-kasus diatas ditengarai masih banyak kasus-kasus yang melibatkan anak yang seharusnya bisa diselesaiakan melalui jalur luar pengadilan dengan pendekatan restorative justice namun karena kenormatifan oknum penegak hukum kita banyak kasus-kasus yang melibatkan anak itu tetap dibawa ke ranah pengadilan, bahkan tidak sedikit dari mereka yang harus di penjarakan. Padahal pemenjaraan bagi orang dewasa saja merupakan upaya terahir atau ultimum remidium lalu apakah pantas pemenjaraan diberikan sebagai akibat dari kenakalan anak?, apalagi jikalau perbuatan kenakalan itu masih dalam batasan yang bisa ditolelir (bukan bermaksud memberikan toleransi kepada semua perbuatan nakal/criminal yang dilakukan anak, tetapi toleransi ini perlu kita sematkan setelah sebelumnya membandingkan antara motif perbuatan, akibat dari perbuatan dan akibat dari penerapan hukuman).

Anak masih harus tumbuh dan berkembang menjadi dewasa dan terbebas dari stigma sebagai anak kriminil.Selain itu masih sangat diragukan bahwa pemenjaraan itu mampu menjerakan anak dari perbuatan nakal atau membina mereka agar tidak berperilaku kriminal. Keraguan penulis ini berdasarkan kunjungan penulis ke Lapas Anak di Kutoarjo pada tanggal 11 Agustus tahun 2012 yang lalu, dari pengamatan dan wawancara singkat dengan anak binaan dan petugas Lapas maka penulis bisa menyimpulkan, bahwa sangat sulit mengharapkan adanya perubahan perilaku dari "pemenjaraan" anak di Lapas jikalau anak dalam tingkatan umur digabung, tidak ada pengawasan yang intens, dan tidak ada program yang memadahi guna melakukan rekontruksi perilaku. Hal ini belum bisa dipenuhi oleh Lapas Anak Kutoarjo yang merupakan salah satu Lapas Anak rujukan di Indonesia. Lapas anak hanya seperti tempat berkumpulnya anak-anak nakal, alih-alih mereka akan mendapatkan pembinaan perubahan perilaku, justru mungkin saja ini adalah tempat pembelajaran tindak kriminal bagi anak. ${ }^{5}$ Oleh karena itu perlu berfikir ulang untuk melakukan pemenjaraan terhadap anak jikalau masih ada alternatiflain yang lebih manjur sebagai upaya mendatangkan keadilan dan perlindungan bersama.

3 Koran Suara Merdek, Edisi 30 Januari 2012, hlm. 1

4 Solopos Online, 11 Maret 2016

5 Penyataan Kalapas Anak Kutoarjo. 11 Agustus 2012 


\section{HUMANISASI HUKUM PIDANA ANAK}

Menjadikan hukum berkeadilan bukanlah menegakkan hukum untuk hukum itu sendiri. Seperti yang telah dikemukan oleh Oliver Wendell Holmes, "The supreme court is not of justice, it is a court of law", melainkan untuk menegakkan hukum demi keadilan, baik bagi individu maupun bagi masyarakat, bangsa dan negara, bahkan keadilan yang dimaksud adalah keadilan demi Tuhan Yang Maha Esa, sehingga terciptanya suasana kehidupan bermasayarakat yang aman, tenang, tenteram, tertib dan damai ${ }^{6}$ Oleh karena itu apapun yang dilakukan hukum atau aparat penegak hukum dalam mencari kebenaran harus berorientasi pada keadilan dan perlindungan.

Sejak dahulu sampai sekarang energi masyarakat kita telah banyak terkuras untuk melakukan pembahasan mengenai hukum pidana sebagai upaya untuk membangun kontruksi sosial. Meningkatnya angka kriminalitas dari tahun-ketahun telah menuntut kerja keras dalam membangun pemikiran-pemikiran baru mengenai arah kebijakan hukum di masa depan. Arah kebijakan hukum bertujuan menjadikan hukum sebagai aturan yang memberikan perlindungan bagi hak-hak warga Negara dan menjamin kehidupan generasi di masa depan. Oleh karena itu sistem hukum tiap Negara dalam praktiknya terus mengalami modernisasi sebagai jawaban atas tuntutan masyarakat akan keadilan, dan tidak ada satu Negara pun yang dapat menolaknya. Pemikiran modern yang berkembang akhir-akhir ini semakin terlihat terutama masalah sistem pemidanaan berupa sanksi pidana yang diberikan kepada seseorang yang melakukan tindak pidana.

Salah satu topik perbicangan hangat yakni mengenai pengesampingan hukuman penjara. Kecenderungan untuk tidak selalu menggunakan sanksi pidana penjara sudah didengungkan oleh beberapa negara di dunia dengan melakukan perubahan dan pembaharuan dalam aturan hukum pidananya.Teori klasik mengenai tujuan penidanaan berupa pembalasan nampaknya sedikit demi sedikit mulai dijauhi dengan mengedepankan bahwa tujuan pemidanaan tidak hanya mengenai pembalasan semata, namun harus dilihat secara menyeluruh, yakni tidak hanya memberikan perlindungan terhadap masyarakat tetapi juga termasuk memberikan perlindungan bagi korban serta pelaku tidak pidana. Dengan kata lain pemidanaan tidak hanya berbicara masalah pembalasan, namun juga bagaimana hukuman tetap memanusiakan manusia (Humanistik), mengembalikan para pelaku kejahatan ke dalam masyarakat setelah menjalani hukuman dan memperbaharui perilaku pelaku tindak pidana menjadi lebih baik, baik dari segi moral maupun dari segi kemampuan diri sehingga dengan begitu mereka dapat hidup dengan baik di dalam masyarakat. Oleh karena itu kritik terhadap pemidanaan penjara sering muncul dikalangan ahli hukum, hal ini didasarkan pada kemampuan hukuman penjara untuk mengembalikan pelaku tindak pidana ke masyarakat sebagai salah satu tujuan pokok pemidanaan.

Seperti yang kita ketahui, ketika berbicara masalah penjatuhan hukum pidana, secara umum kita mengenal ada tiga teori yakni:

\section{a. Teori Pembalasan}

Teori ini bisa juga disebut dengan teori absolut atau teori retributif, yang dimaksudkan untuk membalas tindakan pidana yang dilakukan seseorang. Pembalasannya ditujukan untuk kesalahan pembuat karena tercela(corak subjektif) dan pembalasan dilakukan oleh orang yang bersangkutan (corak objektif) ${ }^{7}$

b. Teori Tujuan

Teori ini lahir atas kritik dari adanya teori pembalasan. Teori ini juga dapat disebut sebagai teori utilitarian, yang tujuannya bukanlah sekedar sebagai pembalasan akan tetapi mewujudkan ketertiban dalam masyarakat. ${ }^{8}$

6 Antonius Sudirman, Hati Nurani hakim dan Putusannya, Suatu Pendekatan dari Perspektifilmu Hukum Perilaku (Behavior Jurisprudence) Kasus Hakim Bisma Siregar, (Bandung: PT Citra Adhitya Bakti, 2007), hlm. 1.

7 Bambang Poernomo, Asas-asas Hukum Pidana,(Jakarta: Ghalia Indonesia, 1976), hlm.27-28.

8 Muladi dan Barda Nawawi Arief, Teori-teori dan Kebijakan Pidana, (Bandung: Alumn, 1979), hlm. 16. 


\section{c. Teori Gabungan}

Teori ini menitikberatkan pada suatu kombinasi dari teori absolut dan teori relatif. Tujuan dari teori ini selain untuk membalas kesalahan penjahat juga dimaksudkan untuk melindungi masyarakat dengan mewujudkan ketertiban. ${ }^{9}$

Satu hal yang patut dicatat berkaitan dengan perkembangan teori pemidanaan tersebut adalah adanya pergeseran orientasi pemidanaan dari prinsip menghukum (punishmentfor punishment) yang cenderung mengabaikan aspek hak asasi manusia kearah gagasan/ide pembinaan (treatment, maatregelen) yang lebih menghargai dan menjunjung tinggi hak asasi manusia berkaitan dengan masalah tujuan pemidanaan ini. Hal ini sependapat dengan Muladi yang pada intinya menyatakan, bahwa dalam konteks Indonesia maka teori pemidanaan yang cocok digunakan dalam sistim hukum pidana adalah kombinasi tujuan pemidanaan yang didasarkan pada aspek sosiologis, idiologis dan yuridis filosifis masyarakat Indonesia sendiri, teori pemidanaan ini disebut sebagai teori pemidanaan yang integratif (kemanusiaan dalam sistim Pancasila) dimana hal tersebut berarti adalah bagaimana suatu hukuman dapat memuat pembalasan dan tujuan untuk merekonstruksi narapidana sehingga ketika narapidana keluar dari Lembaga Pemasyarakatan dapat dengan mudah menyesuaikan diri bersama masyarakat. ${ }^{10}$

Menurut Barda Nawawi Arif, efektifitas hukum pidana dapat dilihat dari dua aspek pokok tujuan dari pemidanaan, yaitu aspek perlindungan masyarakat dan aspek perbaikan perilaku dari si pelaku yang dimaksud dengan aspek perlindungan masyarakat meliputi tujuan dari mencegah, mengurangi atau mengendalikan tindak pidana dan memulihkan keseimbangan masyarakat (antara lain menyelesaikan konflik, mendatangkan rasa aman, memperbaiki kerugian atau kerusakan, menghilangkan noda-noda, memperkuat kembali nilai-nilai yang hidup di dalam masyarakat). Aspek perbaikan si pelaku meliputi berbagai tujuan, antara lain melakukan rehabilitasi dan memasyarakatkan kembali si pelaku dan melindunginya dari perlakuan sewenang-wenang di luar hukum. ${ }^{11}$

Dilihat dari aspek perlindungan atau kepentingan masyarakat, maka suatu pemidanaan dikatakan efektif apabila pemidanaan itu sejauh mungkin dapat mencegah dan mengurangi kejahatan atau tindak pidana. ${ }^{12} \mathrm{Jadi}$, efektifitas pemidanaan dilihat dari seberapa jauh frekuensi kejahatan atau tindak pidana dapat ditekan. Dengan demikian, kreterianya terletak pada seberapa jauh efek pencegahan umum (general prevention) dari pidana penjara dalam mencegah warga masyarakat pada umumnya untuk melakukan kejahatan.

Aspek dari si pelaku juga dapay dilihat, maka ukuran efektifitas terletak pada aspek pencegahan khusus (special prevention) dari pemidanaan., ukuranya adalah pada masalah seberapa jauh pemidanaan itu (penjara) mempunyai pengaruh terhadap si pelaku dua aspek pemidanaan terhadap terpidana ada 2 (dua), yaitu aspek pencegahan awal (deterent aspect) dan aspek perbaikan (reformative aspect).Aspek pencegahan awal biasanya diukur dengan menggunakan indicator residifis.Berdasarkan indikator inilah RM. Jackson mengatakan bahwa suatu pidana dikatakan efektif ketika si pelanggar tidak dipidana lagi dalam suatu periode tertentu.Selanjutnya ditegaskan, bahwa efektifitas pemidanaan diukur melalui perbandingan antara jumlah pelanggar yang dipidana

9 J.M.Van Bemmelem, Hukum Pidana I Hukum Pidana Materiil Bagian Umum, (Bandung: Bina Cipta, 1984), hlm.137-138.

10 Tongat, Pidana Seumur Hidup dalam Sistem Hukum Pidana di Indonesia.(Malang: Universitas Muhammadiyah Malang, 2001), hlm.71.

11 Barda Nawawi Arif. Dalam Dwidja Priyatno, Sistem Pelaksanaan Pidana Penjara di Indonesia, (Bandung: Refika Aditama, 2006), hlm. 82.

12 Barda Nawawi Arif, Bunga Rampai Kebijakan Hukum Pidana, (Bandung: Citra Aditya Bakti, 2002), hlm. 224225 . 
lagi dan yang tidak dipidana kembali. ${ }^{13}$ Selanjutnya aspek perbaikan berhubungan dengan masalah perubahan sikap dari terpidana. Seberapa jauh hukuman penjara mampu mengubah sikap terpidana, masih merupakan masalah yang belum dapat dijawab secara memuaskan. Hal ini disebabkan adanya beberapa problem metodologis yang belum terpecahkan dan belum ada kesepakatan, khususnya mengenai: ${ }^{14}$

1. Apakah ukuran untuk menentukan telah adanya "tanda-tanda perbaikan atau perubahan sikap pada diri si pelaku"; ukuran residivism rate atau reconviction rate masih banyak yang meragukan.

2. Berapa lamanya periode tertentu untuk melakukan evaluasi terhadap ada tidaknya perubahan sikap setelah terpidana menjalani pidana penjara. Berdasarkan masalah-masalah metodologis yang dikemukakan di atas dapatlah dinyatakan, penelitian-penelitian selama ini belum dapat membuktikan secara pasti apakah penjara itu efektif atau tidak, terlebih ketika kita berbicara masalah efektifitas pemidanaan yang berkaitan dengan berbagai faktor. ${ }^{15}$

Keraguan mengenai keberhasilan tujuan pemidanaan khususnya pidana penjara sering dibarengi dengan berbagai kritik. Kritik terhadap pidana penjara pada dasarnya berorientasi pada dua pandangan: ${ }^{16}$

1. Kritik yang moderat; pada intinya masih mempertahankan pidana penjara, namun kecenderungan penggunaanya dibatasi secara limitative dan selektif.

2. Kritik yang ekstrim; yang menghendaki hapusnya sama sekali hukuman penjara. Gerakan penghapusan pidana penjara (Prison abolition) ini terlihat dengan diselenggarakannya International Conference On Prison Abolition (ICOPA), yang deselenggarakan pertama kali pada tahun 1983 di Toronto, Kanada, kemudian yang kedua diselenggarakan di Amsterdam pada tahun 1985, dan yang ketiga diselenggarakan di Montela, Kanada pada tahun 1987 yang kemudian mengubah istilah prison abolition dengan istilah penal apolition.

Salah satu tokoh prison abolition adalah Herman Bianchi, yang mengatakan: The institution of prison and imprisonment are to be for ever abolished, entirely and totally. No trace should be lift of this darkside in human history.(Lembaga pidana penjara harus dihapuskan untuk selamalamanya dan secara menyeluruh, tidak sedikitpun bekas yang bisa diambil dari sisi yang gelap di dalam sejarah kemanusiaan ini). ${ }^{17}$

Atas dasar kritik diatas maka I.J. "Cy" Shain seorang peneliti dari Judicial Council Of California berpendapat, bahwa terdakwa yang memenuhi syarat-syarat tertentu sebaiknya tidak dipidana penjara. Adapun syarat-syarat itu adalah sebagai berikut: ${ }^{18}$

1. Terdakwa selain tidak termasuk penjahat "profesional" juga tidak banyak mempunyai riwayat kriminal;

2. Dalam melakukan tindak pidana banyak faktor-faktor yang meringankan;

3. Terdakwa tidak melakukan ancaman atau menyebabkan penderitaan atau kerugian yang serius pada korban-korbannya;

4. Fakta-fakta menunjukkan bahwa terdakwa melakukan kejahatan karena ada provokasi dari si korban;

13 RM. Jackson. Dalam Dwidja Priyatno, Sistem Pelaksanaan Pidana Penjara di Indonesia, (Bandung: Refika Aditama, 2006), hlm. 83.

14 Ibid hlm.84.

15 Barda Nawawi Arif, Op. Cit. hlm. 225-230.

16 Ibid hlm. 230.

17 Barda Nawawi Arif, Kapita Selekta Hukum Pidana, (Bandung: Citra Aditya Bakti, 2003), hlm. 33-34.

18 Barda Nawawi arif, Kebijakan Legislatif Dengan Pidana Penjara, (Semarang: Badan Penerbit UNDIP, 1996), hlm:149. 
5. Terdakwa bersedia memberikan gantu rugi atas kerugian yang didera si korban

6. Tidak terdapat cukup alasan yang menunjukkan, bahwa terdakwa akan melakukan tindak pidana ulang.

Bertolak dari penjatuhan pidana khususnya pidana penjara yang bersifat ultimum remidiumdan mencermati permasalahan diatas, maka penulis berpendapat perlunya langkah baru guna memperbaharui sistem pemidanaan kita. Bukan untuk mengahapuskan pidana penjara, namun bagaimana sebisa mungkin "mengesampingkan" pidana penjara khususnya untuk bagi anak dengan merujuk kreteria yang disampaikan oleh "Cy" Shain seperti tersebut diatas. Hal ini didasarkan bahwa dunia penjara itu adalah dunia yang "keras", sehingga jangan sampai hanya karena perbuatan sebagai wujud kenakalan, seorang anak harus dipenjara dan harus menghadapi berbagai fenomena negatif yang ada di dunia penjara. Karena jika itu yang terjadi, alih-alih mendorong anak menjadi individu lebih baik, justru bisa jadi penjara menjadi akademi atau ruang pembelajaran tindak kriminal bagi mereka.

Reformasi serta kritik-kritik yang selama ini ada terkait sistem dan penegakan hukum di Indonesia memberikan kesempatan kepada kita untuk memikirkan tentang apa yang akan kita lakukan untuk keluar dari situasi buruk. Namun bagaimanapun suasana keterpurukan masih menyisakan berkah, yaitu memberikan kesempatan kepada kita untuk memikirkan perubahan secara tidak tanggung-tanggung bahkan memikirkan sampai pada akar filosofi sekalipun, termasuk melakukan pembaharuan mengenai pemidanaan yakni pengesampingan hukuman penjara khususnya untuk kasus pidana yang melibatkan anak di dalamnya.

\section{PENERAPAN PENDEKATANRESTORATIF JUSTICE SEBAGAI ALTERNATIF PENYELESAIAN TINDAK PIDANA CYBER DENGAN PELAKU ANAK USIA SEKOLAH}

J.E. Sahetapymengatakanperdamaian tanpa adanya keadilan adalah sebuah penindasan, dan keadilan tanpa perdamaian adalah bentuk baru penganiayaan. ${ }^{19}$ Tidak selamanya sanksi pidana yang pada prinsipnya bertujuan memberikan penghukuman berupa pengasingan menjadi jalan terakhir bagi setiap pelaku tindak pidana khususnya anak. Pengasingan bukanlah suatu solusi yang terbaik dalam menyelesaikan masalah-masalah kejahatan yang melibatkan anak. mengkondisikan kejahatan sebagai sebuah keniscayaan untuk selalu mendapatkan pemenjaraan merupakan hal yang ironis .Jangan menjadi seperti mereka (pembuat aturan era kolonial), di mana orang-orang yang tidak mampu berdialog dengan hati nurani dan memasrahkan diri kepada tatanan yang terlanjur irasional dan bengkok. ${ }^{20}$ Sebaliknya dengan menggunakan falsafah integrasi solutif yang terdapat pada sila Keempat Pancasila, yakni Musyawarah merupakan prioritas yang utama untuk mencapai kebijaksanaan yang adil dan menciptakan perdamaian. Falsafah seperti itulah yang dalam hal ini bisa dijadikan alternatif atau cara lain penyelenggaraan peradilan kriminal dengan melakukan pendekatan integrasi atau pembauran antara pelaku dengan korban hingga menjadi satu kesatuan yang utuh untuk mencari solusi dengan harapan dapat kembali pada suatu hubungan yang baik dalam masyarakat nantinya. Alternatif penghukuman inilah yang biasa disebut sebagai restorative justice.

Restorative justice adalah proses penyelesaian tindakan pelanggaran hukum yang terjadi, yang dilakukan dengan membawa korban dan pelaku (tersangka) bersama-sama duduk dalam satu pertemuan untuk bersama-sama berbicara, dalam pertemuan itu mediator memberikan kesempatan kepada pihak pelaku untuk memberikan gambaran sejelas-jelasnya mengenai tindakan yang telah dilakukannya. Pihak pelaku yang melakukan pemaparan sangat mengharapkan pihak korban untuk dapat menerima dan memahami kondisi dan penyebab kenapa pelaku melakukan tindak

19 J.E. Sahetapy, Suatu studi khusus Mengenai Ancaman hukuman Mati terhadap Pembunuhan Berencana, (Jakarta: Rajawali pers, 1982) hlm. 56.

20 Koran Tempo, Habitus Politik dan Keniscayaan, Kamis, 24 Oktober 2013, hlm. A10. 
pidana yang menyebabkan korban mengalami kerugian.Kemudian pelaku juga memaparkan tentang pertanggungjawabannya mengenai perbuatan yang telah dilakukannya.Kemudian hal itu ditanggapi oleh korban, dan selain itu juga hadir masayarakat sebagai pihak yang ikut dirugikan secara umum. ${ }^{21}$ Jadi pendekatan Restorative justice menawarkan penyelesaian perkara pidana yang melibatkan anak, cukup diselesaiakn lewat jalur mediasi antara pelaku, korban dan masyarakat sebagai pihak yang menjadi korban sekaligus sebagai pihak yang harus ikut bertanggungjawab atas perilaku yang dilakukan anak sebagai pelaku kejahatan, sebab masyarakat atau orang tualah yang harusnya menjadi pihak yang paling bertanggung jawab atas perbuatan anak. Karena sering kali anak-anak melakukan tindak pidana itu setelah sebelumnya "belajar" dari perilaku menyimpang orang tua atau masyarakat. ${ }^{22}$ Pendek kata, wacana mengenai perlindungan terhadap anak yang mengatakan anak adalah manusia muda dalam umur muda, dalam jiwa muda dan dalam perjalanannya mudah terpengaruh untuk keadaan sekitar, ${ }^{23}$ itu artinya dalam keadaan seperti itu menuntut hukum untuk berperilaku "istimewa" terhadap anak, dan penyelesaian perkara anak di luar pengadilan dan anti pemenjaraan adalah jawabannya.

Perlu kita ingat bahwa menyelesaikan persoalan pidana tidak bisa terpaku dalam ranah penal saja, karena pada dasarnya ending dari keberadaan hukum bukan hanya menghukum pelaku tindak pidana, tetapi bagaimana hukum mampu mendamaikan, menentramkan masyarakat. Menurut Rusli Muhammad,tujuan jangka panjang dari hukum (system hukum/peradilan pidana) adalah terciptanya tingkat kesejahteraan yang menyeluruh dikalangan masyarakat. ${ }^{24}$ Tidak hanya itu, demi menjaga kedamaian dan ketentraman masayarakat, bukan hal yang berlebihan dan bukan sesuatu yang luar biasa jikalau sistem peradilan kita digeser dari peradilan retributif kepada peradilan restoratif, atau restorative justice. Adapun perbedaan peradilan retributive dan peradilan restorative seperti yang dikemukakan oleh Mahmud Mulyadi adalah sebagai berikut: ${ }^{25}$

\begin{tabular}{clll}
\hline No & \multicolumn{1}{c}{ Tema Pokok Keadilan } & \multicolumn{1}{c}{ Retributif } & \multicolumn{1}{c}{ Restoratif } \\
\hline 1. & Orientasi keadilan & $\begin{array}{l}\text { Kepada Pelanggar dan karena } \\
\text { pelanggarannya }\end{array}$ & $\begin{array}{l}\text { Kepada kepentingan } \\
\text { umum }\end{array}$ \\
2. & Kejahatan & Melanggar Negara & $\begin{array}{l}\text { Melanggar hak } \\
\text { perorangan }\end{array}$ \\
3. Korban & Negara & $\begin{array}{l}\text { Orang dirugikan } \\
\text { langsung, masyarakat, }\end{array}$ \\
& & $\begin{array}{l}\text { Negara dan pelaku sendiri } \\
\text { Menyelesaikan konflik }\end{array}$ \\
4. Sistem Peradilan Pidana pelanggar dan & $\begin{array}{l}\text { Menjatuhkan pidana sebagai } \\
\text { rasionalisasi pembalasan }\end{array}$ & $\begin{array}{l}\text { antara pelanggar dengan } \\
\text { korbannya }\end{array}$ \\
& & $\begin{array}{l}\text { Pidana } \\
\text { pembalasanatas pelanggaran } \\
\text { hukumpidana }\end{array}$ & $\begin{array}{l}\text { Pertanggung jawaban } \\
\text { akibatperbuatannya }\end{array}$ \\
5. Pemidanaan & Bersifat Pasif & Bersifat Aktif \\
\hline
\end{tabular}

21 Marlina, Peradilan Pidana anak di Indonesia: Pengembangan Konsep Diversi dan Restorative Justice, (Bandung: Refika Aditama, 2009), hlm. 180-181.

22 Ibid

23 RA Koesman, 1998, Susunan pidana dalam Negara Sosialis Indonesia, sumur Bandung, Bandung, hal: 113

24 Rusli Muhammad, Sistem Peradilan Pidana Indonesia (Yogyakarta: UII Press, 2011), hlm. 4.

25 Mahmud Mulyadi, "Perlindungan terhadap Anak yang Berkonflik dengan Hukum: Upaya Menggeser Keadilan Retributive Menuju Keadilan Restorative”, Jurnal Equality, Vol. 13 No.1 Februari 2008, hlm. 88. 


\section{Kejahatan Cyber dengan Pelaku Anak Usia Sekolah dan Tawaran Penyelesaiannya}

Kemajuan teknologi telah memberikan dampak yang cukup signifikan dari berbagai aspek kehidupan manusia.Perkembangan teknologi yang semakin pesat dan dorongan kebutuhan manusia yang semakin meningkat untuk menembus batas ruang dan waktu, maka terbentuklah sebuah media yang bisa mempermudah setiap orang untuk menjalin komunikasi dan berinteraksi jarak jauh yang sering disebut dengan Dunia Maya.

Komunikasi dunia maya merupakan salah satu fasilitas yang digunakan untuk berbagai kegiatan atau aktifitas seperti yang dilakukan di dunia nyata, oleh sebab dikarenakan banyak kesamaan antara dunia nyata dengan dunia maya maka perlu adanya etika dalam berkehidupan di dalam kedua dunia tersebut.Internet merupakan produk teknologi abad ini yang sedang berkembang di dunia, termasuk di Indonesia. Dengan internet seseorang dapat melakukan beberapa aktivitas secara bersamaan tanpa harus keluar rumah, misalnya berdiskusi, belanja, transfer uang, kuliah dan lain-lain. Ini merupakan sisi positif dari internet.Namun internet tidak lepas dari sisi negatif berupa pemanfaatannya sebagai media untuk melakukan kejahatan yang dikenal dengan istilah cyber crime.Volodymyr Golubevmenyebutnya sebagai "the new form of anti-social behavior" ada beberapa jenis kejahatan ini, misalnya economic cyber crime, cyber terrorism, cyber stalking, cyber sex dan cyberporn. ${ }^{26} \mathrm{Hal}$ ini menunjukkan bahwa segala bentuk kejahatan di dunia nyata telah terjadi pula di dunia maya.

Sebelum internet muncul, pada era sebelumnya hukum menghadapi tantangan berupa kejahatan komputer.J.E Sahetapy pernah menyatakan bahwa hukum pidana yang ada tidak siap menghadapi kejatahan komputer, karena tidak segampang itu menganggap kejahatan komputer berupa pencurian data sebagai pencurian. Kalau dikatakan pencurian, tentu harus ada barang yang hilang, padahal dalam kejahatan komputer, data si pemilik masih ada kendati sudah dicuri orang lain. ${ }^{27}$

Seperti yang disampaikan diatas bahwa banyak sekali manfaat yang dapat kita ambil dari Dunia Internet/dunia mayatapi pada kenyataanya banyak orang memanfaatkan Internet sebagai media untuk melakukan tindak kejahatan, propaganda, penghinaan, pornografi dan lain sebagainya. Banyak sekali berita-berita di tv, radio, koran yang menginformasikan mengenai kejahatan di dunia internet, salah satunya yang hendak penulis bahas dalam makalah ini, yakni seorang siswa SMP kelas 2 yang harus berurusan dengan polisi karena diadukan gurunya karena si murid telah melakukan penghinaan melalui dunia maya.

Kejadian ini terjadi di salah satu SMP di kabupaten Boyolali pada Pertengahan tahun 2013 yang lalu.Pelaku dengan inisial BST ini adalah siswa kelas 2 SMP dengan umur 15 Tahun.Berawal dari ketersinggungan BST yang sering dimarahi guru bahasa Jawa dengan inisial SS (perempuan) maka BST mengambil foto SS dan kemudian mengupload foto tersebut diakun Fecebook. Sebelum BST mengupload foto tersebut, terlebih dahulu BST melakukan editing foto SS dengan seolaholah SS sedang merokok dan membubuhi kata-kata "iki guru ra cetho". ${ }^{28}$

Oleh SS kemudian perbuatan BST tersebut dilaporkan kepada kepala Sekolah dan ke polisi yang berujung pada pemanggilan orang tua SS oleh pihak sekolah dan menyatakan BST dikeluarkan dari sekolah tersebut. Selain itu BST juga harus berurusan dengan polisi karena sebelumnya SS dan keluarganya telah bersikukuh untuk membawa kasus ini secara hukum, yang itu artinya BST bisa dijerat menggunakan Undang-Undang Nomor 11 Tahun 2008 Tentang Informasi dan Transaksi Elektronik dan telah dianggap melakukan Cyber Crime. Perbuatan BST ini disandarkan pada Pasal 27 ayat 3 yakni larangan bagi Setiap Orang dengan sengaja dan tanpa hak mendistribusikan dan/atau mentransmisikan dan/atau membuat dapat diaksesnya Informasi Elektronik dan/atau

26 Volodymyr Golubev, Cyber-crime and legal problems of Internet usage, p.1; Zaporizhia Law Institute, Ministry of Interior of Ukraine.

27 Widyopramono, Kejahatan di Bidang Komputer, (Jakarta: Pustaka Sinar Harapan, 1994), hlm. 44.

28 Dokumen Kronologi kasus, Badan Konsultasi dan Bantuan Hukum fakultas Hukum Universitas Muhammadiyah Surakarta 
dokumen elektronik yang memiliki muatan penghinaan dan/atau pencemaran nama baik. Yang mana menurut Pasal 45 ayat 1 ancaman hukumannya adalah penjara paling lama 6 (enam) tahun dan/atau denda paling banyak Rp1.000.000.000,00 (satu miliar rupiah).

Pasal 28B Undang-Undang Dasar1945 mengatakan:"Setiap anak berhak atas kelangsungan hidup, tumbuh, dan berkembangserta berhak atas perlindungan dari kekerasan dan diskriminasi", dan Pasal 4 Undang-Undang No.23 Tahun 2002 Tentang Perlindungan Anak juga menyatakan : 'Setiap anak berhak untuk dapat hidup, tumbuh, berkembang, danberpartisipasi secara wajar sesuai dengan harkat dan martabatkemanusiaan serta mendapat perlindungan dari kekerasan dan diskriminasi. Itu artinya dalam kondisi apapun anak harus tetap dapat tumbuh dan berkembang sebagaimana mestinya, dan bagi mereka yang berhadapan dengan hukum harus mendapat keadilan secara filosofis termasuk menggeser pendekatan hukum retributifkearahrestoratif.

Dengan semangat arus restoratifjustice maka kasus yang melibatkan "si anak kreatif” BST ini kemudian dapat diselesaikan di luar peradilan dengan menggunakan pendekatan restoratif, yakni proses penyelesaian tindakan pelanggaran hukum yang terjadi, yang dilakukan dengan membawa korban dan pelaku (tersangka) bersama-sama duduk dalam satu pertemuan untuk bersama-sama berbicara, dalam pertemuan itu mediator memberikan kesempatan kepada pihak pelaku untuk memberikan gambaran sejelas-jelasnya mengenai tindakan yang telah dilakukannya. Pihak pelaku yang melakukan pemaparan sangat mengharapkan pihak korban untuk dapat menerima dan memahami kondisi dan penyebab kenapa pelaku melakukan tindak pidana yang menyebabkan korban mengalami kerugian.Kemudian pelaku juga memaparkan tentang pertanggungjawabannya mengenai perbuatan yang telah dilakukannya.Kemudian hal itu ditanggapi oleh korban, dan selain itu juga hadir masayarakat sebagai pihak yang ikut dirugikan secara umum. Dalam kasus BST ini ada beberapa pihak yang dilibatkan dalam upaya penyelesaian perkara yakni:
1. Pelaku
: BST
2. Orang Tua BST : BSN
3. Korban :SS
4. Mediator : BKBH Universitas Muhammadiyah Surakarta
5. Masyarakat : Kepala sekolah Perwakilan siswa

Forum mediasi dibuka oleh mediator dengan memberikan uraian sigkat mengenai filosofi hukum dan keadilan.Mediator kemudian memberikan kesempatan kepada BST untuk menyampaikan gambaran sejelas-jelasnya mengenai tindakan yang telah dilakukannya. BST juga mengatakansangat mengharapkan pihak SS untuk dapat menerima dan memahami kondisi dan penyebab kenapa pelaku melakukan tindak pidana yang menyebabkan SS mengalami "kerugian" dan untuk itu BST minta maaf serta berjanji untuk tidak mengulai serta siap merubah perilaku. Kemudian BST juga memaparkan tentang pertanggungjawabannya mengenai perbuatan yang telah dilakukannya.Penyataan BST kemudian ditanggapi oleh SS yang disaksikan oleh oleh mediator, Orang tua BST, Kepala sekolah dan Siswa. Dalam mediasi tersebut ada beberapa kesepakatan yaitu:

1. Menerapkan sanksi bina sosial untuk BST, yakni:

a. Mewajibkan BST untuk menjadi folunteer di laboratorium komputer sekolah sebagai pendamping guru komputer dalam mengajar materi praktik selama 3 bulan, hal ini dikarenakan BST memang dikenal mempunyai kemampuan lebih dalam bidang IT dibanding teman-temannya yang lain.

b. Mewajibkan BST untuk mengikuti program kajian keislaman yang disiapkan khusus oleh pihak sekolah selama 1 bulan untuk pembinaan perilaku.

c. Mewajibkan bagi orang tua BST untuk memberikan pendampingan khusus untuk BST di Sekolah selama 1 bulan.

2. Mencabut keputusan sekolah untuk mengeluarkan BST. 
Upaya yang dilakukan oleh para pihak dalam kasus diatas terlihat sebagai upaya yang sederhana, tapi didalamnya mengandung filosofi keadilan yang mendalam.Hukum bukan hanya diartikan sebagai pasal-pasal yang selalu kaku namun hukum adalah norna untuk menuju keserasian.

\section{KESIMPULAN}

Sistem peradilan pidana yang menawarkan win and lost bagi para pihak yang perkara dan memberikan konskuensi pidana (penjara) bagi mereka dirasa sebagai praktik yang tidak seharusnya terjadi untuk kasus-kasus yang melibatkan anak khususnya bagi meraka pelaku cyber crime. karena penjara bukanlah tempat yang semestinya untuk tumbuh kembang anak dan pemenjaraan sama dengan pelanggaran terhadap hak dasar anak. Oleh karena itu restorative Justicehadir sebagai sebuah tawaran penyelesaian perkara pidana bagi anak pelaku cyber crime, restorative justice lahir sebagai upaya merubah wajah hukum pidana anak yang dehumanis menjadi humanis.

\section{DAFTAR PUSTAKA}

Arif, Barda Nawawi, 2003, Kapita Selekta Hukum Pidana, Bandung: Citra Aditya Bakti =-------2002, Bunga Rampai Kebijakan Hukum Pidana, Bandung: Citra Aditya Bakti -,1996, Kebijakan LegislatifDengan Pidana Penjara, Semarang: Badan Penerbit UNDIP , Muladi, 1979, Teori-teori dan Kebijakan Pidana, Bandung: Alumn

Golubev, V, Cyber-crime and legal problems of Internet usage, p.1; Zaporizhia Law Institute, Ministry of Interior of Ukraine

Koesman,R.A, 1998, Susunan Pidana Dalam Negara Sosialis Indonesia, Bandung: Sumur Bandung

Marlina, 2009, Peradilan Pidana anak di Indonesia: Pengembangan Konsep Diversi dan Restorative Justice, Bandung: Refika Aditama

Muhammad, R, 2011, Sistem Peradilan Pidana Indonesia, Yogyakarta: UII Press

Mulyadi,M, "Perlindungan terhadap Anak yang Berkonflik dengan Hukum: Upaya Menggeser Keadilan Retributive Menuju Keadilan Restorative", Jurnal Equality, Vol. 13 No.1 Februari 2008

Poernomo, B, 1976, Asas-asas Hukum Pidana, Jakarta: Ghalia Indonesia

Priyatno,D, 2006, Sistem Pelaksanaan Pidana Penjara di Indonesia, Bandung: Refika Aditama

Sahetapy,J.E, 1982, Suatu studi khusus Mengenai Ancaman hukuman Mati terhadap Pembunuhan Berencana, Jakarta: Rajawali Pers

Sudirman, A, 2007, Hati Nurani Hakim dan Putusannya, Suatu Pendekatan dari Perspektif ilmu Hukum Perilaku (Behavior Jurisprudence) Kasus Hakim Bisma Siregar, Bandung: PT Citra Adhitya Bakti

Tongat, 2001, Pidana Seumur Hidup dalam Sistem Hukum Pidana di Indonesia. Malang: Universitas Muhammadiyah Malang

Van Bemmelem,J.M., 1984, Hukum Pidana I Hukum Pidana Materiil Bagian Umum, Bandung: Bina Cipta

Widyopramono, 1994, Kejahatan di Bidang Komputer, Jakarta: Pustaka Sinar Harapan 


\section{REFERENSI LAIN}

Undang-Undang Nomor 11 Tahun 2008 Tentang Informasi dan Transaksi Elektronik

Dokumen Kronologi kasus, Badan Konsultasi dan Bantuan Hukum Fakultas Hukum Universitas Muhammadiyah Surakarta 